storage form ${ }^{8}$-given $2 \mathrm{~h}$ before testing, also prevented the motor hyperactivity induced by morphine.

We conclude that at least some of the behavioural effects of morphine administration can be reversed by pre-treatment with drugs which affect biogenic amine metabolism. The specificity of some of these effects was demonstrated by their elimination when amine precursors (5-hydroxytryptophan and x-DOPA) were administered in conjunction with PCPA and AMPT, respectively. While no gross alterations of total biogenic amine levels have been found to result from single or multiple doses of morphine ${ }^{9,10}$, the evidence for morphine-induced alterations in amine turnover rates is rather definite. Thus Gunne $^{1}$ and Haubrich and Blake ${ }^{11}$ have shown that the brain levels and the urinary excretion of 5-hydroxy. indoleacetic acid and of catecholamine metabolites are increased substantially after administration of morphine, and Way et al. have shown increased accumulation of serotonin in morphinized animals treated with a monoamine oxidase inhibitor, compared with non-morphine treated controls ${ }^{2}$. If increases in rate of turnover-rather than increases in the total (free and stored) levelsof the amines are the consequence of morphine treatment, two possible conclusions are suggested. Either the activities of rate-limiting enzymes concerned in the synthesis of the amines increase following morphine or, perhaps more likely, amine re-uptake into storage forms ${ }^{12,13}$ is impeded by morphine, thus increasing tho amount of free amines available for synaptic transmission and metabolic degradation. Recent reports on the antagonism between reserpino and morphine ${ }^{14,15}$ and the interference we have found between imipramine and morphine support the second alternative, which also requires fewer assumptions. We now plan to test this hypothesis directly. If morphine is indeed found to interfere significantly with the uptake of serotonin and norepinephrine, our behavioural results would lead us to expect differences in the degree and duration of this interference, to account for the well known differences in the effects of morphine in tolerant and non-tolerant animals.

\section{E. Eidelberg}

A. S. Schwartz

Division of Neurobiology,

Barrow Neurological Institute,

St Joseph's Hospital,

Phoenix, Arizona 85013.

Received September 19; revised December 11, 1969.

1 Gunne, L. M., Actc Physiol. Scand., 62, Suppl. 204 (1963).

Way, E. L., Loh, H. H., and Shen, F. H., Science, 162, 1290 (1968).

'Takagi, H., and Kuriki, H., Intern. J. Neuropharm., 8, 195 (1969)

- Koella, W. P., Feldstein, A., and Czicman, J. S., Electroenceph. Clin. Neurophysiol., 25, 481 (1968).

Koe, K. B., and Weissman, A., J. Pharmacol. Exp. Therap., 154, 499 (1966).

- Spector, S., Sjoerdsma, A., and Udenfriend, S., J. Pharmacol. Exp. Therap. 147, 86 (1965).

- Carlsson, A., Lindqvist, M., Fuxe, K., and Hokfelt, T., J. Pharm. Pharmacol., 18, 60 (1966).

- Glowinski, J., and Axelrod, J., Nature, 204, 1318 (1964).

- Maynert, E. W., and Klingman, G. I., J. Pharmacol. Exp. Therap., 135, 285 (1962).

${ }^{10}$ Cochin, J., and Axelrod, J., J. Pharmacol. Exp. Therap.,125, 105 (1959).

11 Haubrich, D. R., and Blake, D. E., Fed. Proc., 28, 2985 (1969).

${ }^{12}$ von Euler, U. S., and Hillarp, N. A., Nature, 177, 44 (1956).

18 Carlsson, A., Hillarp, N. A., and Waldeck, B., Acta Physiol. Scand., 59, Supp. 215 (1963)

Is Smith, A., Lisper, K., and Hayashida, K., Fed. Proc., 28, 15 (1969).

"shen, F. S., Loh, H. H., and Way, E. L., Fed. Proc., 28, 2986 (1969).

\section{Schizophrenia as a Genetic Morphism}

THE incidence of schizophrenia in most communities is of the order of 1 per cent. Yet the fertility of schizophrenic males is low, as noted by Huxley et al. ${ }^{1}$; and it has since been established that the fertility of schizophrenic females is low, too ${ }^{2}$. The second observation serves to strengthen the suggestion of Huxley et al. that the fertility of schizophrenics seems too low for the disorder to be maintained at its present rate by mutation alone. In explanation they noted the resistance of schizophrenies to surgical and wound shock, to visceral perforation, to high doses of histamine, insulin and thyroxine, and to pain. They noted also the possibility that schizophrenics may be resistant to diseases such as smallpox and bubonic plague which have occurred in widespread epidemics.

Moran ${ }^{3}$ suggested that the proposed robustness of the schizophrenic genotype might be manifested at an earlier stage of life: "I therefore suggest that the presence of a gene for schizophrenia has a protective effect for one or more of the genetic factors which cause the loss of fertilized ova".

It may be worth noting that the only two relevant studies known to me do not support Moran on this point. These suggested that, in contrast with control samples, there was a higher incidence of foetal loss among the sibs of schizophrenic propositi ${ }^{4}$, and that there was a higher proportion of miscarriages among the pregnancies of psychotic women (64 per cent of whom had been diagnosed as schizophrenic) ${ }^{5}$.

There are two problems about the incidonee of schizophrenia: in the first place it scems very high, and in the second it seems not to be declining (as it should be if a schizophrenic gene protected its bearer against bubonic plague or smallpox). I can offer no fresh answer to the first. In regard to the second, it seems possible to me that either the level of schizophrenia is being maintained by an increasing degree of psychological stress to which we are said to be exposed, or that a true decline in schizophrenic rates is being masked by less extreme critoria of definition. Possibly one does not have to be so mad these days to be called "schizophrenic".

I am supported by a grant from the Population Council of New York.

Department of Biometry,

Galton Laboratory,

University College, London.

Received July 25, 1969; revised January 23, 1970.

${ }^{1}$ Huxley, J., Mayr, E., Osmond, H., and Hoffer, A., Nature, 204, 220 (1964).

2 Stevens, B., Brit. Med. J., 4, 22 (1969).

Moran, P. A. P., Nature, 206, 1111 (1965).

4 'Terris, M., Lapouse, R., and Monk, M. A., Amer. J. Psychiat., 121, 476 (1964).

${ }^{5}$ Winokur, G., Guze, S. B., and Pfeiffer, E., Amer. J. Psychiat., 115, 1097 (1959).

\section{Possible Relationships between Orienting and Diving Reflexes}

THE diving reflex has been studied extensively in aquatic organisms that breathe air and submerge to obtain food or to escape from predators such as ducks, seals and alligators ${ }^{1}$. This reflex seems to have two phases: an initial phase which may be mediated by the vagus and trigeminal nerves $^{2}$, and a later one which follows prolonged holding of the breath during voluntary or forcible submersion ${ }^{3}$. The initial phase includes bradycardia ${ }^{1,4}$, apnoea (specifically, an interruption of respiration $)^{1,4}$, peripheral vasoconstriction $^{4,5}$ and cephalic vasodilation ${ }^{5}$. Gaunt and Gans ${ }^{6}$ have reported that bradycardia in Caiman crocolilius is minimal during spontaneous dives but great during the approach of an investigator or during handling. They suggest that early diving bradycardia is mainly "psychogenic" in origin and results from "threatoning" stimuli. We have been studying (ref. 7 and unpublished results) the responses of the wholly aquatic salamander Necturus maculosus (mudpuppy) and have noted similarities to the early components of diving, specifically bradycardia and an interruption of respiration. (Necturus breathes through 